УДК 323:351

https://doi.org/10.34142/24130060.2020.20.1.13

\title{
КОНЦЕПТУАЛІЗАЦІЯ ПОНЯТЬ «НАЦІОНАЛЬНА БЕЗПЕКА» І «ДЕРЖАВНА БЕЗПЕКА» У ПОЛІТИКО-ПРАВОВОМУ ДИСКУРСІ
}

\author{
Г. М. Куц
}

Харківський національний педагогічний університет імені Г. С. Сковороди

У статті здійснено концептуалізацію понять «національна безпека» та державна безпека» у політико-правовому контексті. Категорія національної безпеки є ширшою, ніж категорія державної безпеки, шьо є важливим маркером демократичності політичної системи певної держави.

Аргументовано, щуо у конщептуальній демаркації понять «національна безпека» та «державна безпека» вагомого значення набуває тип політичного режсму в державі. Чим більш розвинуте демократичне суспільство, тим легше виявити концептуальні відмінності між обома дефініціями. За умов домінування недемократичного політичного режиму у державі (тоталітаризм/авторитаризм) конщептуальні ознаки циих понять «зливаються», щуо врешті призводить до їх ототожнення.

Ключові слова: національна безпека, державна безпека, політико-правовий дискурс, політичний режим, демократія, концептуалізація.

\section{КОНЦЕПТУАЛИЗАЦИЯ ПОНЯТИЙ «НАЦИОНАЛЬНАЯ БЕЗОПАСНОСТЬ» И «ГОСУДАРСТВЕННАЯ БЕЗОПАСНОСТЬ» В ПОЛИТИКО-ПРАВОВОМ ДИСКУРСЕ}

\author{
Г. М. Куц
}

В статье осуществлена конщептуализация понятий «национальная безопасность» u «государственная безопасность» в политико-правовом контексте. Категория национальной безопасности шире, чем категория государственной безопасности, что является важным маркером демократичности политической системы конкретного государства.

Аргументировано, что в концептуальной демаркаџии понятий «национальная безопасность» и «государственная безопасность» большое значение приобретает тип политического режима в государстве. Чем более развито демократическое общество, тем легче выявить концептуальные различия между обеими дефинициями. В условиях доминирования недемократического политического режима в государстве (тоталитаризм/авторитаризм) концептуальные признаки этих понятий «сливаются», что в конечном итоге приводит к их отождествлению.

Ключевые слова: национальная безопасность, государственная безопасность, политико-правовой дискурс, политический режим, демократия, концептуализация. 


\section{CONCEPTUALIZATION OF THE CONCEPTS OF «NATIONAL SECURITY» AND «STATE SECURITY» IN THE POLITICAL AND LEGAL DISCOURSE}

\section{H. Kuts}

The article conceptualizes the concepts of «national security» and «state security» in the political and legal context. These concepts are quite similar in content. At the same time, the political and legal explication of these categories demonstrates differences in the understanding of their essence and areas of application. The category of national security is broader than the category of state security, which is an important marker of the democracy of a country's political system.

It is argued that in the conceptual demarcation of the concepts of «national security» and «state security» the type of political regime in the state becomes important. The more developed a democratic society, the easier it is to identify conceptual differences between the two definitions. Given the dominance of an undemocratic political regime in the state (totalitarianism / authoritarianism), the conceptual features of these concepts «merge», which ultimately leads to their equation.

In the liberal-democratic discourse, the key ideologues of which have become the basis of the modern discourse of the rule of law, a clear line is drawn between society and the state. Under the conditions of a developed democracy, the state can safely delegate even the issue of ensuring the security of citizens from the «center» to the «regions».

State security is one of the important key components of national security. In a simplified form, it can be noted that the category of «national security» is correlated with all spheres of public life, while the category of state security - with the functioning of state institutions that ensure the implementation of its policies.

The issue of state security is characterized by concern for the protection and defense of the state against internal and external threats. The concept of national security, in addition to the outlined issues of the discourse of state security, also covers a range of issues related to the successful existence and development of society, with the protection of its values. We are talking primarily about such values as quality of life, social solidarity, human rights, culture, customs, national identity and so on. The classical definition of state security can be applied to any state, regardless of the political regime inherent in a particular political system. The definition of national security is clearly correlated with democratic political systems, as it covers ensuring the security of civil society structures.

Key words: national security, state security, political and legal discourse, political regime, democracy, conceptualization.

Постановка проблеми. Проблематика безпеки - одна 3 ключових для політико-правового та державно-управлінського дискурсів. Це пов'язано 3 тим, що індивід, як зазначав Ш.-Л. Монтеск’є (1955, s. 165-166), перебуваючи у природному стані, насамперед потребує безпеки та спокою. В означеному контексті, однією з первинних функцій держави є забезпечення безпеки своїх громадян. 
Сучасна Українська держава потребує виваженої та ефективної безпекової політики, яка б формувалася у руслі пріоритетних національних інтересів України. Захист демократичних цінностей, здобутків демократії є надактуальним для політичного простору сучасної України, проти якої з 2014 року ведеться гібридна війна з боку Росії. У Доктрині інформаційної безпеки України зазначається, що формування державної інформаційної політики має бути спрямованим на протидію «руйнівному інформаційному впливу Російської Федерації в умовах розв'язаної нею гібридної війни» (Ukaz Prezydenta Ukrainy, 2016). Базовою ознакою сучасних гібридних війн вважається активне ведення інформаційних війн. Технології гібридної війни спрямовані на руйнування досягнень демократії шляхом використання інструментарію демократичного дискурсу.

Означене коло проблем актуалізує проблематику дослідження політико-безпекового дискурсу, зокрема, здійснення концептуальної демаркації між категоріями «національна безпека» та «державна безпека».

Аналіз актуальних досліджень. Проблематиці безпеки присвячено наукові праці багатьох вітчизняних та зарубіжних теоретиків суспільнополітичного, державно-управлінського, політико-правового дискурсів (T. Бальзак, 3. Бжезінський, М. Вавринчук, О. Власюк, В. Горбулін, О. Дзьобань, К. Дунай, В. Кітлер, В. Ліпкан, В. Мадіссон, В. Олуйко, Г. Ситник, В. Смолянюк, О. Чуваков, М. Чужик, В. Шахов та ін.).

Метою статті стало здійснення концептуалізації понять «національна безпека» та державна безпека» у політико-правовому дискурсі. Завдання статті полягає у політико-правовій експлікації категорій «національна безпека» та «державна безпека» у контексті проблематики політичних режимів.

Виклад основного матеріалу. Концепти «національна безпека» та державна безпека» є доволі близькими у змістовному плані. Разом 3 тим, політико-правова експлікація означених категорій демонструє відмінності у розумінні їхньої сутності та сфер їхнього застосування. 
Задля концептуальної демаркації дефініцій «національна безпека» та державна безпека» звернемося насамперед до Закону України «Про національну безпеку України».

Під національною безпекою України (стаття 1, пункт 9) мається на увазі «захищеність державного суверенітету, територіальної цілісності, демократичного конституційного ладу та інших національних інтересів України від реальних та потенційних загроз» (Zakon Ukrainy, 2018).

Державна безпека, згідно із Законом України «Про національну безпеку України» (стаття 1, пункт 4) - це «захищеність державного суверенітету, територіальної цілісності і демократичного конституційного ладу та інших життєво важливих національних інтересів від реальних і потенційних загроз невоєнного характеру» (Zakon Ukrainy, 2018).

Отже, у визначенні поняття «державна безпека» є багато спільних концептуальних ознак з поняттям національної безпеки. Втім, є важливі нюанси, які вказують на відмінність специфічних ознак цих концептів.

Задля кристалізації розуміння концептуальних ознак означених дефініцій варто навести ще й визначення поняття «воєнна безпека» (стаття 1 , пункт 2), під якою мається на увазі «захищеність державного суверенітету, територіальної цілісності і демократичного конституційного ладу та інших життєво важливих національних інтересів від воєнних загроз» (Zakon Ukrainy, 2018).

Як бачимо з наведених визначень, паритетною конфронтантою для поняття «державна безпека» можна вважати категорію «воєнна безпека». Ці ідеологеми взаємовиключні і застосовуються в різних умовах суспільнополітичного буття. У проблематиці державної безпеки на передньому плані захищеність «від реальних і потенційних загроз невоєнного характеру», тоді як для проблематики воєнної безпеки більш вагомою є захищеність «від воєнних загроз».

Стосовно ж розуміння взаємозв'язку ідеологем національної безпеки та державної безпеки - конфронтантності не спостерігається. Ці категорії, 
доповнюючи одна одну у змістовному плані, демонструють, 3 одного боку, певну спільність концептуальних ознак. 3 іншого боку, спостерігається певна підпорядкованість категорії «державна безпека» категорії «національна безпека». Відповідно, категорія національної безпеки $є$ ширшою, ніж категорія державної безпеки, що $є$ важливим маркером демократичності політичної системи України.

Слід зазначити, що у державах 3 демократичним типом політичної системи поняття суспільства та держави не ототожнюються. Разом 3 тим, у суспільно-філософському дискурсі існували напрямки філософської думки, в яких поняття суспільство і держава ототожнювалися (філософія Платона, марксизм). Це ототожнення було реалізовано також на практиці (міста-поліси в Стародавній Греції; радянська політична система). Вважалося, що суспільство і держава - одне і те ж, тобто держава має право втручатися в різноманітні сфери суспільного життя. При такому розумінні зникає грань відмінностей між приватним і громадським. При такому ототожненні суспільства і держави відразу девальвується поняття особистості. I, дійсно, роль окремого індивіда і в Афінській демократії, і в СРСР була незначною. Вважалося, що колектив $\epsilon$ важливішим, ніж індивід. Більше того, ототожнення суспільства та держави свідчить про недемократичність політичної системи, про тоталітарний характер її політичного режиму.

У демократичних країнах - розвинуте громадянське суспільство. Громадянське суспільство формується 3 вільних громадян, які живуть у межах встановлених законом, з гарантованими індивідуальними правами при обмеженні повноважень уряду та за умови демократичної підзвітності. У таких умовах держава виступає лише у ролі інструменту для служби громадянам, вона покликана поважати принципи демократичної підзвітності. Причому, сильне громадянське суспільство та конституційна демократія у сукупності здатні забезпечити стабільну основу для політичного порядку.

У ліберально-демократичному дискурсі (Дж. Локк, Т. Гоббс, І. Кант, Л. Мізес, Ф. Хайєк та ін.), ключові ідеологеми якого стали основою 
сучасного дискурсу правової держави, проводиться чітка межа між суспільством і державою. Вважається, що державі не дозволено втручатися в приватне життя індивіда. Держава обмежена в своїх діях правом, що захищає свободу індивіда, його безпеку та гідність. Правова демократична держава характеризується тим, що підкоряє владу волі суверенного народу (Kuts, 2002). Права людини є неподільними та універсальними, вони не залежать ні від громадянства конкретної держави, ні від приналежності до тієї чи іншої етнічної або соціальної групи, статі, релігії чи політичної партії (Kuts, Kuts ta Lisnychyi, 2002). Втім, до конфлікту з індивідуальними свободами і правами людини може призводити державна влада, особливо, коли панівним політичним режимом у державі стає тоталітаризм.

Ліберально-демократичний світогляд визнає, у цілому, ідеал індивідуальної свободи в якості універсальної мети (Kuts, 2011). Самоцінність індивіда, його відповідальність не лише перед суспільством, але й перед собою, право на самореалізацію кожного, вільний розвиток та самоствердження складають основу принципу свободи особистості, який $є$ базовим для всього ліберального дискурсу.

Французький дослідник проблематики національної безпеки Т. Бальзак зазначає, що безпека, як «панівний принцип ліберальної традиції», стала умовою держави. I люди відчувають себе захищеними тоді, коли захищена держава (Balzacq, 2003, p. 37). Держава є водночас складною організаційною структурою, громадою та інструментом політики. У цьому сенсі держава - це насамперед інструмент просування безпеки (Balzacq, 2003, p. 34).

За умов розвинутої демократії держава може сміливо делегувати 3 «центру» в «регіони» навіть питання забезпечення безпеки громадян (Kuts red., 2011). Наприклад, на початку 70-х років XX ст., зазначає Р. Д. Патнам, почалися активні процеси децентралізації в Італії. Саме тоді відповідальність за безпеку, за охорону здоров'я тощо перейшла від центрального до місцевих урядів (Patnam, Leonardi ta Nanetti, 2001, s. 17). 
Таким чином, оскільки у державах з демократичним типом політичної системи поняття суспільства та держави не ототожнюються, відсутнє й ототожнення концептів «національна безпека» та «державна безпека». У спрощеному вигляді можна зазначити, що категорія «національна безпека» співвідноситься 3 усіма сферами суспільного життя, тоді як категорія державної безпеки - 3 функціонуванням інституцій держави, що забезпечують здійснення їі політики.

На думку польської дослідниці К. Дунай, для проблематики державної безпеки характерними є питання турботи про охорону та оборону держави перед внутрішніми та зовнішніми загрозами (Czuryk and etc. 2016, s. 20.). Поняттям національної безпеки, окрім окреслених питань дискурсу державної безпеки, охоплюється ще й коло проблем, пов'язаних з успішним існуванням та розвитком суспільства, із захистом його цінностей. Мова насамперед йде про такі цінності як якість життя, суспільну солідарність, права людини, культуру, звичаї, національну ідентичність тощо. У порівнянні з поняттям державної безпеки, дефініція національної безпеки ширша, вона охоплює потреби та цінності різноманітних суспільних груп. Саме реалізація таких цінностей є метою діяльності демократичних держав. Адже класична дефініція державної безпеки може бути застосовною щодо кожної держави, не зважаючи на політичний режим, який притаманний певній політичній системі. Дефініція ж національної безпеки чітко співвідноситься саме 3 демократичними політичними системами, оскільки нею охоплюється забезпечення безпеки структур громадянського суспільства (яких в принципі не може існувати в умовах тоталітарного політичного режиму).

Як слушно зазначає український теоретик О. Власюк, «одним iз важливих ключових складників національної безпеки є державна безпека» (Vlasiuk, 2016, s. 26). Відповідно, поняття національної безпеки не можна звужувати до поняття державної безпеки чи ототожнювати 3 ним. Національна безпека України забезпечується діяльністю суспільних 
інституцій, що спрямована на створення та вдосконалення умов і детермінант ефективної життєдіяльності народу. Тобто, суспільні інституції утворюють систему забезпечення національної безпеки України.

На підпорядкованість поняття державної безпеки дефініції національної безпеки також вказує О. Чуваков: «у зв’язку із появою поняття «національна безпека» термін «державна безпека» набув більш вузького значення та означає створення таких умов, які б забезпечували непорушність існуючого конституційного ладу, суверенітет і територіальну цілісність держави» (Chuvakov, 2012, s. 193).

Досить своєрідно ототожнює поняття національної безпеки та державної безпеки польський теоретик В. Кітлер, аналізуючи проблематику безпеки в контексті демократичного дискурсу. Він зазначає, що національна безпека - це, власне, державна безпека (демократичної держави) (Kitler, 2014, s. 25). Разом з тим, такі підходи до розуміння співвідношення понять національної безпеки та державної безпеки $є$ поодинокими та фрагментарними.

Отже, у концептуальній демаркації понять «національна безпека» та «державна безпека» вагомого значення набуває тип політичного режиму в державі. Чим більш розвинуте демократичне суспільство, тим легше виявити концептуальні відмінності між обома дефініціями. За умов домінування недемократичного політичного режиму у державі (тоталітаризм/авторитаризм) концептуальні ознаки цих понять «зливаються», що врешті призводить до їх ототожнення. Тобто, наявність відмінностей між поняттями «національна безпека» та «державна безпека» $є$ своєрідним маркером демократичності політичної системи держави.

Згідно з Конституцією України (стаття 17), «забезпечення державної безпеки і захист державного кордону України покладаються на відповідні військові формування та правоохоронні органи держави, організація i порядок діяльності яких визначаються законом» (Verkhovna Rada Ukrainy, 1996). У відповідності із Законом України «Про національну безпеку 
України», забезпечення державної безпеки покладається на Національну гвардію України (стаття 18, пункт 5); Службу безпеки України (стаття 19, пункт 1).

Задля поглибленого розуміння сфери застосування поняття державної безпеки звернемося до «Стратегії національної безпеки України» (від 06.05.2015 р.) (Указ Президента України, 2015). У статті 4.4. Стратегії мова йде про необхідність реформування Служби безпеки України. Зокрема, зазначається, що концентрацію зусиль слід спрямувати на забезпечення «державної безпеки у сферах боротьби з тероризмом, економічної, інформаційної, кібернетичної безпеки» (Ukaz Prezydenta Ukrainy, 2015). Тобто, чітко окреслюється проблематика державної безпеки: боротьба 3 тероризмом, економічна безпека, інформаційна безпека, кібернетична безпека. Власне кажучи, ця сфера застосування поняття державної безпеки означена ще в Конституції України, де наголошується (стаття 17), що забезпечення «економічної та інформаційної безпеки є найважливішими функціями держави» (Verkhovna Rada Ukrainy, 1996).

Отже, поняття національної безпеки більш широке і всеохопне у порівнянні з поняттям державної безпеки. Згідно з Конституцією України, національну безпеку забезпечує Президент України (стаття 106, пункт 1) (Verkhovna Rada Ukrainy, 1996). А координаційним органом 3 питань національної безпеки i оборони при Президентові України є Рада національної безпеки і оборони України (стаття 107).

У державах демократичного типу поняття національної безпеки переважно співвідноситься з усіма сферами суспільного життя. Також цим поняттям охоплюється і функціонування державних інституцій. На цьому наголошується у статті 3 Закону України «Про національну безпеку України»: державна політика у сфері національної безпеки спрямована як на захист людини і громадянина, так і на захист держави (Zakon Ukrainy, 2018). 
Основні принципи, які визначають порядок формування державної політики у сфері національної безпеки в Україні, наступні (Zakon Ukrainy, 2018):

1) принцип верховенства права, підзвітність, законність, прозорість та дотримання основ демократичного цивільного контролю щодо сектору безпеки і оборони та застосування сили;

2) дотримання норм міжнародного права, участь у забезпеченні інтересів України у міжнародних зусиллях з підтримання миру та безпеки, міждержавних системах та механізмах міжнародної колективної безпеки;

3) розвиток сектору безпеки та оборони як базового інструменту реалізації державної політики у сферах національної безпеки та оборони.

До ключових структурних аспектів національної безпеки України, на думку О. Власюка, слід віднести: державно-політичний аспект; соціальноекономічний аспект; національно-культурний аспект; екологічний аспект; інформаційний аспект (Vlasiuk, 2016).

Цікавим у контексті розрізнення категорій національної безпеки та державної безпеки $є$ той факт, що в Україні здійснюється підготовка здобувачів вищої освіти як за спеціальністю «Національна безпека», так і за спеціальністю «Державна безпека». Ці спеціальності відносяться до галузі знань - «25 Воєнні науки, національна безпека, безпека державного кордону». Більш поширеною $є$ спеціальність «Національна безпека (за окремими сферами забезпечення і видами діяльності)». Метою освітньої програми цієї спеціальності є забезпечення публічного сектору «висококваліфікованими фахівцями для соціально-економічної, соціальнополітичної, соціально-особистісної, оборонної, контрольної, аналітичної та дослідницької діяльності в галузі управління й адміністрування національною безпекою» (Kafedra politolohii ta natsionalnoi bezpeky, 2019). Зазначається, що спеціальність «національна безпека» спрямована також на підготовку кваліфікованих фахівців із питань державної безпеки. Тобто, поняттям національної безпеки охоплюється поняття державної безпеки. 
Аналогічні спеціальності існують, наприклад, у вищих навчальних закладах Польщі: «Національна безпека» (Bezpieczeństwo narodowe) та «Державна безпека» (Bezpieczeństwo państwa). Слід зазначити, що специфіка відмінностей між означеними спеціальностями приблизно та ж сама, що й в Україні.

У розумінні специфіки відмінностей між дефініціями національної безпеки та державної безпеки важливого значення набуває ідеологема «національні інтереси», яке $є$ ключовою ідеологемою для політикобезпекового дискурсу.

Важливість ідеологеми національних інтересів обумовлюється тим, що «основні напрями політики національної безпеки визначаються національними інтересами, тому визначення національних інтересів має передувати формуванню політики, яка забезпечує національну безпеку» (Shakhov ta Madisson, 2013, s. 51).

Національні інтереси України, згідно із Законом України «Про національну безпеку України» (стаття 1, пункт 10) - це «життєво важливі інтереси людини, суспільства i держави, реалізація яких забезпечує державний суверенітет України, iї прогресивний демократичний розвиток, а також безпечні умови життєдіяльності і добробут iii громадян» (Zakon Ukrainy, 2018).

Національні інтереси за своєю спрямованістю «зорієнтовані на забезпечення виживання та прогресивний розвиток i, певною мірою, лідерства особи, суспільства, держави» (Shakhov ta Madisson, 2013, s. 46). Перманентна невизначеність та ментальна розбіжність у формуванні основних критеріїв задля визначення національного інтересу - це ознака розколотості суспільства та несформованості нації.

Формування та реалізація національних інтересів мають бути прерогативою перш за все держави, яка володіє монопольним правом на легітимну інтерпретацію загальнонаціональних пріоритетів. Разом 3 тим, «національний інтерес віддзеркалює єдність прагнень громадянського 
суспільства і держави» (Shakhov ta Madisson, 2013, s. 50). Тобто, держава не $\epsilon$ єдиним учасником реалізації національних інтересів. У демократичному соціумі на процеси формування та реалізації національних інтересів здійснюють вплив різноманітні актори: владні інституції різних рівнів, бізнесові структури, структури громадянського суспільства, політичні партії, релігійні організації (Liakhovych, 2017) тощо.

На важливості цінностей свободи, демократії, патріотизму наголошується у Доктрині інформаційної безпеки України. Зокрема зазначається, що з-поміж пріоритетів державної політики в інформаційній сфері щодо забезпечення захисту i розвитку інформаційного простору України має бути пропагування «досвіду державотворення, цінностей свободи, демократії, патріотизму, національної єдності, захисту України від зовнішніх і внутрішніх загроз» (Ukaz Prezydenta Ukrainy, 2016). В означеному контексті, Українська держава потребує виваженої інформаційної політики, спрямованої на забезпечення іiі національних інтересів задля ефективності процесу демократичних трансформацій.

Висновки і перспективи подальших досліджень. Таким чином, концепти «національна безпека» та державна безпека»є доволі близькими у змістовному плані. Разом з тим, політико-правова експлікація означених категорій демонструє відмінності у розумінні їхньої сутності та сфер їхнього застосування.

Категорія національної безпеки $є$ ширшою, ніж категорія державної безпеки, що $є$ важливим маркером демократичності політичної системи певної держави. Слід зазначити, що у державах 3 демократичним типом політичної системи поняття суспільства та держави не ототожнюються. Ототожнення суспільства та держави свідчить про недемократичність політичної системи, про тоталітарний характер їі політичного режиму. У ліберально-демократичному дискурсі, ключові ідеологеми якого стали основою сучасного дискурсу правової держави, проводиться чітка межа між суспільством і державою. За умов розвинутої демократії держава може 
сміливо делегувати 3 «центру» в «регіони» навіть питання забезпечення безпеки громадян.

Оскільки у державах 3 демократичним типом політичної системи поняття суспільства та держави не ототожнюються, відсутнє й ототожнення концептів «національна безпека» та «державна безпека». У спрощеному вигляді можна зазначити, що категорія «національна безпека» співвідноситься 3 усіма сферами суспільного життя, тоді як категорія державної безпеки - 3 функціонуванням інституцій держави, що забезпечують здійснення її політики.

Для проблематики державної безпеки характерними є питання турботи про охорону та оборону держави перед внутрішніми та зовнішніми загрозами. Поняттям національної безпеки, окрім окреслених питань дискурсу державної безпеки, охоплюється ще й коло проблем, пов'язаних 3 успішним існуванням та розвитком суспільства, із захистом його цінностей. Мова насамперед йде про такі цінності як якість життя, суспільну солідарність, права людини, культуру, звичаї, національну ідентичність тощо. У порівнянні з поняттям державної безпеки, дефініція національної безпеки ширша, вона охоплює потреби та цінності різноманітних суспільних груп. Саме реалізація таких цінностей є метою діяльності демократичних держав. Адже класична дефініція державної безпеки може бути застосовною щодо кожної держави, не зважаючи на політичний режим, який притаманний певній політичній системі. Дефініція ж національної безпеки чітко співвідноситься саме 3 демократичними політичними системами, оскільки нею охоплюється забезпечення безпеки структур громадянського суспільства (яких в принципі не може існувати в умовах тоталітарного політичного режиму).

Отже, у концептуальній демаркації понять «національна безпека» та «державна безпека» вагомого значення набуває тип політичного режиму в державі. Чим більш розвинуте демократичне суспільство, тим легше виявити концептуальні відмінності між обома дефініціями. За умов домінування 
недемократичного

політичного

режиму

$\mathrm{y}$

державі

(тоталітаризм/авторитаризм) концептуальні ознаки цих понять «зливаються», що врешті призводить до їх ототожнення.

\section{ЛІТЕРАТУРА}

1. Власюк, О. С. 2016. Національна безпека України: еволючія проблем внутрішньої політики. Київ: НІСД.

2. Закон України, 2018. Про національну безпеку України: Закон України від 21.06.2018 p. № 2469-VIII. [online] Доступно:

https://zakon.rada.gov.ua/laws/show/2469-19 [Дата звернення 18 Жовтень 2019].

3. Кафедра політології та національної безпеки, 2019. Національний університет «Острозька академія». [online] Доступно: https://www.oa.edu.ua/ua/departments/politics /pim_polit/ [Дата звернення 18 Жовтень 2019].

4. Верховна Рада України, 1996. Конституиія України. [online] Доступно: https://zakon.rada.gov.ua/laws/show/254\%D0 $\% \mathrm{BA} / 96-\% \mathrm{D} 0 \% \mathrm{~B} 2 \% \mathrm{D} 1 \% 80$ [Дата звернення 18 Жовтень 2019].

5. Куц, Г. М., 2011. Трансформаџійний потениіал лібералізму в політичному npocmopi. Доктор наук. Чернівецький національний університет імені Юрія Федьковича.

6. Куц, Ю. О. ред., 2011. Територіальна громада: знаннєвість, дієвість: монографія. Харків: ХарРІ НАДУ, Апостроф.

7. Куц, Ю. О., 2002. Реалізація прав людини і націй. Юридичний вісник. 1. с. 82-85.

8. Куц, Ю. О., Куць, О. М. та Лісничий, В. В., 2002. Етноначіональні чинники державотворення: монографія. Харків: Вид-во ХарРІ УАДУ «Магістр».

9. Ляхович, Л. М., 2017. Історико-релігійна експлікація проблеми жорстокого поводження 3 тваринами. В: Соціалізація особистості у сучасних соиіокультурних контекстах: VIII Міжнародна науковопрактична конференція. Харків, Україна. 11 Жовтень 2017. Харків: ХНПУ.

10. Монтескье, Ш.-Л., 1955. Избранные произведения. Перевод с французского, ред. И. Щербина. Москва: Государственное издательство политической литературы.

11. Патнам, Р. Д., Леонарді, Р. та Нанетті, Р. Й., 2001. Творення демократії. Традииії

\section{REFERENCES}

1. Vlasiuk, O. S. 2016. Natsionalna bezpeka Ukrainy: evoliutsiia problem vnutrishnoi polityky. Kyiv: NISD.

2. Zakon Ukrainy, 2018. Pro natsionalnu bezpeku Ukrainy: Zakon Ukrainy vid 21.06.2018 r. № 2469-VIII. [online] Dostupno:

https://zakon.rada.gov.ua/laws/show/2469-19

[Data zvernennia 18 Zhovten 2019].

3. Kafedra politolohii ta natsionalnoi bezpeky, 2019. Natsionalnyi universytet «Ostrozka akademiia». [online] Dostupno: https://www.oa.edu.ua/ua/departments/politic s/pim_polit/ [Data zvernennia 18 Zhovten 2019].

4. Verkhovna Rada Ukrainy, 1996. Konstytutsiia Ukrainy. [online] Dostupno: https://zakon.rada.gov.ua/laws/show/254\%D0 \%BA/96-\%D0\%B2\%D1\%80 [Data zvernennia 18 Zhovten 2019].

5. Kuts, H. M., 2011. Transformatsiinyi potentsial liberalizmu $v$ politychnomu prostori. Doktor nauk. Chernivetskyi natsionalnyi universytet imeni Yuriia Fedkovycha.

6. Kuts, Yu. O. red., 2011. Terytorialna hromada: znannievist, diievist: monohrafiia. Kharkiv: KharRI NADU, Apostrof.

7. Kuts, Yu. O., 2002. Realizatsiia prav liudyny i natsii. Yurydychnyi visnyk. 1. s. 82-85.

8. Kuts, Yu. O., Kuts, O. M. ta Lisnychyi, V. V., 2002. Etnonatsionalni chynnyky derzhavotvorennia: monohrafiia. Kharkiv: Vyd-vo KharRI UADU «Mahistr».

9. Liakhovych, L. M., 2017. Istoryko-relihiina eksplikatsiia problemy zhorstokoho povodzhennia z tvarynamy. V: Sotsializatsiia osobystosti u suchasnykh sotsiokulturnykh kontekstakh: VIII Mizhnarodna naukovopraktychna konferentsiia. Kharkiv, Ukraina. 11 Zhovten 2017. Kharkiv: KhNPU.

10. Monteske, Sh.-L., $1955 . \quad$ Izbrannye proizvedeniya. Perevod s francuzskogo, red. I. Sherbina. Moskva: Gosudarstvennoe izdatelstvo politicheskoj literatury.

11. Patnam, R. D., Leonardi, R. ta Nanetti, R. Y., 2001. Tvorennia demokratii. Tradytsii hromadskoi aktyvnosti $v$ suchasnii Italii. 
громадської активності в сучасній Італї. Переклад 3 англійської В. Ющенко. Київ: Видавництво Соломії Павличко «Основи».

12. Указ Президента України, 2015. Про рімення Ради національної безпеки $i$ оборони України «Про Стратегію начіональної безпеки України»: Указ Президента України від 06.05 .2015 p. № 287/2015. [online] Доступно: https://zakon.rada.gov.ua/laws/show/287/2015 [Дата звернення 18 Жовтень 2019].

13. Указ Президента України, 2016. Про рімення Ради начіональної безпеки $i$ оборони Украӥни «Про Доктрину інформаиійної безпеки України»: Указ Президента України від 29.12.2016 p. № 47/2017. [online] Доступно: https://zakon.rada.gov.ua/laws/show/47/2017 [Дата звернення 18 Жовтень 2019].

14. Чуваков, О. А., 2012. Національна і державна безпека: співвідношення понять. Правова держава, 15, с. 193-196.

15. Шахов, В. та Мадіссон, В., 2013. Національний інтерес i національна безпека в геостратегії України. Вісник Національної академії державного управління при Президентові України, 2, c. 44-56.

16. Balzacq, T., 2003. Qu'est-ce que la sécurité nationale? Revue internationale et stratégique, 4(52), p. 33-50.

17. Czuryk, M., Dunaj, K., Karpiuk, M. \& Prokop K., 2016. Bezpieczeństwo państwa: zagadnienia prawne $i$ administracyjne. Olsztyn: Wydział Prawa i Administracji UWM.

18. Kitler, W., 2014. Zakres bezpieczeństwa państwa (narodowego). [online] Доступно: https://www.researchgate.net/publication/3300 15732_Zakres_bezpieczenstwa_panstwa_naro dowego [Дата звернення 18 Жовтень 2019]
Pereklad z anhliiskoi V. Yushchenko. Kyiv: Vydavnytstvo Solomii Pavlychko «Osnovy».

12. Ukaz Prezydenta Ukrainy, 2015. Pro rishennia Rady natsionalnoi bezpeky $i$ oborony Ukrainy «Pro Stratehiiu natsionalnoi bezpeky Ukrainy»: Ukaz Prezydenta Ukrainy vid 06.05.2015 r. № 287/2015. [online] Dostupno: https://zakon.rada.gov.ua/laws/show/287/201 5 [Data zvernennia 18 Zhovten 2019].

13. Ukaz Prezydenta Ukrainy, 2016. Pro rishennia Rady natsionalnoi bezpeky $i$ oborony Ukrainy «Pro Doktrynu informatsiinoi bezpeky Ukrainy»: Ukaz Prezydenta Ukrainy vid 29.12.2016 r. № 47/2017. [online] Dostupno: https://zakon.rada.gov.ua/laws/show/47/2017 [Data zvernennia 18 Zhovten 2019].

14. Chuvakov, O. A., 2012. Natsionalna i derzhavna bezpeka: spivvidnoshennia poniat. Pravova derzhava, 15, s. 193-196.

15. Shakhov, V. ta Madisson, V., 2013. Natsionalnyi interes i natsionalna bezpeka $\mathrm{v}$ heostratehii Ukrainy. Visnyk Natsionalnoi akademii derzhavnoho upravlinnia pry Prezydentovi Ukrainy, 2, s. 44-56.

16. Balzacq, T., 2003. Qu'est-ce que la sécurité nationale? Revue internationale et stratégique, 4(52), p. 33-50.

17. Czuryk, M., Dunaj, K., Karpiuk, M. \& Prokop K., 2016. Bezpieczeństwo państwa: zagadnienia prawne $i$ administracyjne. Olsztyn: Wydział Prawa i Administracji UWM.

18. Kitler, W., 2014. Zakres bezpieczeństwa państwa (narodowego). [online] Доступно: https://www.researchgate.net/publication/330 015732_Zakres_bezpieczenstwa_panstwa_nar odowego [Data zvernennya 18 Zhovten 2019].

\section{Інформація про автора}

Куц Галина Михайлівна, доктор політичних наук, професор, професор кафедри політології, соціології та культурології Харківського національного педагогічного університету імені Г. С. Сковороди; ORCID: http://orcid.org/0000-0002-7263-1958; e-mail:galyna.kuts@i.ua.

Стаття надійшла до редакції: 11.11.2019 р. $\quad$ Прийнята до друку: 29.11.2019 р. 